\title{
Pembelajaran Model SAVI Berpendekatan Kontekstual Terhadap Kemampuan Pemecahan Masalah Matematika Siswa
}

\author{
Prida N.L. Taneo ${ }^{1)}$ \\ 1) Prodi Pendidikan Matematika STKIP SOE, NTT, Indonesia \\ E-mail: nemserayah.19@gmail.com
}

\begin{abstract}
Abstrak. Kemampun Pemecahan masalah siswa menjadi tuntutan tertinggi dalam dunia pendidikan termasuk pembelajaran matematika pada semua jenjang pendidikan, siswa yang yang mempunyai kemampuan pemecahan masalah dengan baik akan mampu berhadapan dengan masalah-masalah nonrutin dan mampu menyusun langkahlangkah dalam menyelesaikan masalah tersebut. Usaha peningkatan kemampuan pemecahan masalah matematika siswa dibentuk dari berbagai macam cara termasuk kreatifitas guru dalam merancang kegiatan pembelajaran dikelas dengan baik melalui penggunaan model dan pendekatan pada kegiatan pembelajaran. Penelitian ini bertujuan untuk mengetahui ketuntasan kemampuan pemecahan masalah siswa menggunakan pembelajaran model SAVI berpendekatan kontekstual; kelas dengan pembelajaran model SAVI dan kelas dengan pembelajaran konvensional. Penelitian ini merupakan jenis penelitian eksperimen semu (quasi-experimental) yang didesain dalam bentuk non-equivalent (pre-test and post-test) control-group design. Penelitian tahap pertama menunjukkan bahwa siswa yang diajarkan menggunakan model SAVI berpendekatan kontekstual tuntas baik individual maupun klasikal, kemampuan pemecahan masalah siswa pada kelas yang diajarkan model SAVI berpendekatan kontekstual lebih baik dari siswa yang diajarkan SAVI lebih baik dari siswa dengan pembelajaran konvensional.
\end{abstract}

Kata Kunci: Kontekstual, Model SAVI, Pemecahan Masalah

\section{PENDAHULUAN}

Pendidikan merupakan usaha sadar yang direncanakan untuk terwujudnya suasana belajar dalam proses belajar mengajar. Dalam UndangUndang Sistem Pendidikan Nasional Nomor 20 Pasal 3 tahun 2003 tentang, tujuan pendidikan nasional adalah mengembangkan potensi siswa agar menjadi manusia yang beriman dan bertakwa kepada Tuhan Yang Maha Esa, berakhlak mulia, sehat, berilmu, cakap, kreatif, mandiri, dan menjadi warga negara yang demokratis serta bertanggung jawab [1]. Untuk mencerdaskan kehidupan bangsa maka perlu adanya pendidikan formal baik dari Sekolah Dasar sampai pada Perguruan Tinggi, berbagai mata pelajaran diajarkan pada bangku pendidikan salah satu diantaranya adalah pendidikan matematika.

Matematika yang merupakan ilmu deduktif, tetapi kebanyakan siswa masih menganggap matematikan sebagai pelajaran yang menakutkan dan sangat abstrak sehingga siswa menganggapnya sebagai pelajaran yang sulit dipahami. Kompetensi yang dikembangkan dalam pelajaran matematika meliputi kemampuan dalam materi matematika dan kemampuan doing math [2]. Kemampuan dalam materi matematika disesuaikan dengan materi atau topik yang dibahas di kelas sesuai dengan jenjang kelas atau sekolahnya, sedangkan kemampuan doing math meliputi matematika sebagai pemecahan masalah (mathematic as problem solving), matematika sebagai kemampuan (mathematics as ability), matematika sebagai penalaran (mathematics as reasoning) dan koneksi-koneksi matematika (mathematical connections). Sehingga dalam pembelajaran matematika hendaknya siswa dibiasakan dengan menyelesaikan masalah sampai pada tahapan tertinggi.

Menurut teori belajar Gagne [3], tahapan yang paling tinggi dalam pembelajaran adalah pemecahan masalah. Dalam pemecahan masalah, siswa dituntut untuk berhadapan dengan masalahmasalah nonrutin dan diharuskan mampu 
menyusun langkah-langkah dalam menyelesaikan masalah tersebut. Para pendidik, matematikawan, dan pihak yang menaruh perhatian pada pendidikan matematika seringkali menetapkan pemecahan masalah sebagai salah satu tujuan pembelajaran matematika Sebagaimana hasil penelitian dari [4], teori dan instruksi merupakan bagian penting dalam pemecahan masalah matematika, oleh karena itu apabila teori dan struktur atau langkahnya telah dipahami dengan baik maka berarti telah menyiapkan langkah awal untuk menikmati dan menumbuhkan minat siswa belajar matematika.

[5] menyatakan bahwa guru merupakan salah satu bagian penting dalam pembelajaran oleh karena itu pelatihan bagi para guru sangat perlu untuk mengejar pembangunan kesadaran siswa dan kemampuan untuk mengaplikasikan pengetahuan mereka pada konteks yang lebih kompleks, mengintegrasikan pengetahuan dengan sikap pribadi mereka dan nilai-nilai kehidupan, kemudian membangun personalitas mereka dan kemampuan profesional. Program pelatihan bagi guru juga harus mengadopsi banyak holistik yang ada (kognitif, didatik, teknikal dan afektif), sehingga guru dapat membelajarkan siswanya dengan baik guna tercapainya tujuan pembelajaran dimaksud.

Usaha-usaha guru dalam membelajarkan siswa merupakan bagian yang sangat penting dalam mencapai keberhasilan tujuan pembelajaran yang sudah direncanakan. Rendahnya daya serap siswa merupakan salah satu masalah pokok dalam pembelajaran pada pendidikan formal (sekolah). Hal ini terlihat dari hasil belajar siswa yang masih relatif rendah, dikarenakan kondisi pembelajaran yang masih bersifat konvensional dan tidak menyentuh ranah dimensi siswa itu sendiri. Dalam arti yang substansial bahwa proses pembelajaran hingga saat ini masih didominasi guru dan tidak memberikan akses bagi siswa untuk berkreasi dan berkembang secara mandiri melalui proses berpikirnya karena pembelajaran yang masih tradisional atau konvensional [6].

Situasi pembelajaran matematika yang konvensional cenderung hanya mengutamakan hasil, tanpa memperhatikan proses pembelajaran dan apa yang terjadi pada siswa. Pembelajaran matematika terkesan menjadi kurang menarik yang berakibat menimbulkan kebosanan, siswa menjadi tidak aktif terhadap kegiatan pembelajaran matematika dan kurang menangkap makna dari apa yang dipelajari sehingga pada akhirnya akan menambah kesulitan belajar matematika mereka, serta prestasi belajar kurang memuaskan. Hal yang serupa juga masih terjadi pada pembelajaran di SMP Negeri 1 Soe. Hasil wawancara penulis dengan pengampu pelajaran matematika SMP Negeri 1 Soe terungkap bahwa kebanyakan guru matematika masih menggunakan pembelajaran konvensional. Perangkat pembelajarannya tidak memuat langkah-lagkah pembelajaran sesuai model pembelajaran yang dipilih, kurang kreatif dalam pemilihan model pembelajaan yang cocok dengan materi ajar dan terkesan pembelajarannya monoton, sehingga siswa tidak bisa menerima pembelajaran dengan baik, kurang kreatif dan tidak trampil ketika menghadapi soal pemecahan masalah, kebanyakan siswa tidak dapat menyelesaikan soal pemecahan masalah yang diberikan oleh gurunya dengan baik. Sedangkan pada Ujian Nasional hampir seluruh soal dalam bentuk pemecahan masalah. Hal ini mengakibatkan ketika siswa menghadapi Ujian Nasional mereka tidak dapat menyelesaikan keseluruhan soal dengan baik dan jika ia berhasilpun, hasil yang diperoleh sangat rendah.

Prestasi belajar mereka pada akhirnya kurang memuaskan, tampak dari perolehan rata-rata nilai hasil Ujian Nasional (UN) pendidikan matematika SMP Negeri 1 Soe tiga tahun terakhir ini yakni tahun 2012 rata-rata nilai UN matematika 4,73; tahun 2013 rata-rata nilai UN matematika 3,90; tahun 2014 rata-rata nilai UN matematika 3,86. Hasil rata-rata nilai UN yang rendah bukan dikarenakan ketidak mampuannya siswa, ini terlihat dari nilai tertinggi UN dari ketiga tahun terakhir sangat baik yakni tertinggi tahun 2012 nilainya 9,75; tahun 2013 nilainya 9,50; dan tahun 2014 nilainya 9,30. Dari perolehan nilai tertinggi ini menunjukkan adanya kemampuan siswa dalam belajar, namun siswa yang mendapat nilai tertinggi mengikuti les tambahan di luar sekolah, sehingga terindikasi ada masalah dalam proses pembelajaran yang mengakibatkan rendahnya hasil belajar tersebut. Penyebabnya adalah 


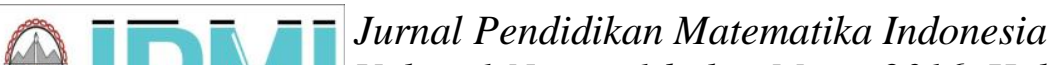 \\ Volum 1 Nomor 1 bulan Maret 2016. Halaman 14-19 \\ p-ISSN: 2477-5967 e-ISSN: 2477-8443}

pembelajaran yang masih konvensional, pembuatan perangkat pebelajaran yang tidak memuat langakah-langlah pembelajaran sesuai model yang telah dipilih, kurangnya penggunaan model pembelajaran yang bervariasi serta penerapan, pemahaman langkah-langkah penyelesaian masalah dan kemampuan pemecahan masalah siswa yang masih lemah, pada umumnya untuk semua materi dan kususnya materi aritmetika sosial.

Berdasarkan hasil wawancra, terdapat lebih dari $50 \%$ siswa yang nilai ulangannya belum memenuhi kriteria ketuntasan minimal. Banyaknya siswa yang belum tuntas nilainya dikarenakan tidak aktif dalam belajar matematika, kurang trampil dalam penyelesaian soal, kurang kreatifnya guru menggunakan model-model pembelajaran dalam mengajar serta terbatasnya sarana pembelajaran, yang berakibat pada rendahnya prestasi belajar. Untuk itu perlu peningkatan sarana dan proses pembelajaran. Salah satu sarana yang perlu dikembangkan adalah perangkat pembelajaran dengan model pembelajaran SAVI berpendekatan kontekstual.

Berdasarkan permasalahan diatas, maka permasalahan yang diteliti pada penelitian ini adalah Apakah kemampuan pemecahan masalah siswa pada kelas yang mendapat pembelajaran model SAVI berpendekatan kontekstual dapat mencapai ketuntasan minimal, apakah kemampuan pemecahan masalah siswa pada kelas yang mendapat pembelajaran model SAVI berpendekatan kontekstual lebih baik dari kelas yang mendapat pembelajaran model SAVI dan lebih baik dari kelas yang mendapat pembelajaran konvensional.

Pembelajaran SAVI yang dengan kepanjanagan Somatis, Auditorial, Visual, dan Intellectual mempunya arti sebagai berikut. Somatis adalah belajar dengan bergerak dan berbuat, Auditorial adalah belajar dengan berbicara dan mendengar, Visual adalah belajar dengan mengamati dan menggambarkan dan Intelektual adalah belajar dengan memecahkan masalah dan merenung [7]. [5] menyatakan bahwa pengembangan kesadaran siswa dan kemampuan untuk mengaplikasikan pengetahuan mereka pada konteks yang lebih kompleks, mengintegrasikan pengetahuan dengan sikap pribadi mereka dan nilai kemudian membangun personalitas mereka dan kemampuan profesional. Pasalnya siswa akan lebih aktif dan tidak hanya duduk diam dan mendengarkan guru berbicara di depan kelas. [7] juga mengemukakan bahwa pembelajaran dengan SAVI adalah pembelajaran yang melibatkan indra pada tubuh yang mendukung pembelajaran, belajar dengan bergerak aktif secara fisik, dengan memanfaatkan indra sebanyak mungkin, dan membuat seluruh tubuh atau pikiran terlibat dalam proses belajar [7]. Pembelajran akan menjadi lebih mudah bagi siswa jika materi yang diajarkan dikaitkan dengan situasi lingkungan atau situasi dunia nyata yang ada dalam kehidupan sehari-hari sehingga mudah dipahami dan tidak terasa abstrak bagi siswa. Nurhadi menjelaskan bahwa "Pendekatan kontekstual merupakan suatu konsep belajar dimana guru menghadirkan situasi dunia nyata ke dalam kelas dan mendorong siswa membuat hubungan antara pengetahuan yang memilikinya dengan penerapannya dalam kehidupan sebagai anggota keluarga dan masyarakat" [8]. Sedangkan menurut Jhonson dalam [9] CTL merupakan suatu proses pengajaran yang bertujuan untuk membantu siswa memahami materi pelajaran yang sedang mereka pelajari dengan menghubungkan pokok materi pelajaran dan penerapannya dalam kehidupan sehari-hari. Jadi, pembelajaran yang mengkaitkan materi ajar dengan dunia nyata yang sering dialami dalam kehidupan sehari-hari siswa, sehingga siswa dengan mudah dapat memhaminya merupakan pembelajaran kontekstual atau Contextual Teaching and Learning.

Pembelajaran dengan pendekatan kontekstual melalui berbagai model dan metodenya, dapat dijadikan sebagai alat untuk membangun karakter [1]. Pendidikan Nasional berfungsi mengembangkan dan mmembentuk karakter serta peradaban bangsa yang bermartabat dalam rangka mencerdaskan kehidupan bangsa [10]. Membangun karakter adalah suatu proses atau usaha yang dilakukan untuk membina, memperbaiki dan atau membentuk tabiat, watak, sifat kejiwaan, akhlak (budi pekerti), insan manusia (masyarakat) sehingga menunjukkan perangai dan tingkah laku yang baik berdasarkan nilai-nilai Pancasila. Pendidikan Nasional 
berfungsi mengembangkan dan mmembentuk karakter serta peradaban bangsa yang bermartabat dalam rangka mencerdaskan kehidupan bangsa [10]. Membangun karakter adalah suatu proses atau usaha yang dilakukan untuk membina, memperbaiki dan atau membentuk tabiat, watak, sifat kejiwaan, akhlak (budi pekerti), insan manusia (masyarakat) sehingga menunjukkan perangai dan tingkah laku yang baik berdasarkan nilai-nilai Pancasila.

Pemecahan masalah merupakan cara yang digunakan dalam menyelesaikan masalah. Menurut Polya [11] solusi soal pemecahan masalah memuat empat langkah penyelesaian yaitu memahami masalah, merencanakan penyelesaian, menyelesaikan masalah sesuai dengan rencana, dan melakukan pengecekan kembali terhadap semua langkah yang telah dikerjakan. Dalam penelitian ini kemampuan pemecahan masalah yang dimaksudkan adalah kemampuan melaksanakan langkah-langkah penyelesaian masalah dengan hasil yang benar dan akurat.

Pemecahan masalah merupakan tujuan yang harus dicapai, meliputi kemampuan mengidentifikasi unsur yang diketahui, ditanyakan, serta kecukupan unsur yang diperlukan; merumuskan masalah dari situasi sehari-hari dalam matematika; menerapkan srategi untuk menyelesaikan berbagai masalah di dalam atau di luar matematika; menjelaskan atau menginterpretasikan hasil sesuai permasalahan asal; menyusun model matematika dan menyesuaikannya pada masalah yang nyata; dan menggunakan matematika secara bermakna standar pemecahan masalah meliputi: (1) membangun pengetahuan matematis baru melalui pemecahan masalah; (2) menyelesaikan masalah yang muncul dalam matematika dan yang lain; (3) menerapkan dan menyesuaikan berbagai macam strategi yang tepat dalam menyelesaikan masalah secara matematis [2].

Pembelajaran Kontekstual yaitu pembelajaran yang memusatkan pada bagaimana siswa mengerti makna dari apa yang mereka pelajari, apa manfaatnya, dalam status apa mereka, bagaimana mencapainya dan bagaimana mereka mendemonstrasikan apa yang telah mereka pelajari [12]. Kerja keras adalah perilaku yang menunjukkan upaya sungguh-sungguh dalam mengatasi berbagai hambatan belajar, tugas, guna menyelesaikan tugas (belajar/pekerjaan) dengan sebaik-baiknya [10].

Dave Meier dalam [13] merupakan pendidik, trainer, sekaligus penggagas model accelerated Learning. Salah satu pembelajarannya adalah apa yang dikenal dengan SAVI. Pembelajaran model SAVI adalah model pembelajaran yang menekankan bahwa belajar haruslah memanfaatkan semua alat indera yang dimiliki siswa. Pembelajaran model SAVI mengandung aliran ilmu kognitif modern yang menyatakan belajar yang baik adalah melibatkan emosi, seluruh tubuh, semua indera dan segenap kedalaman serta keluasan pribadi, menghormati gaya belajar individu lain dengan menyadari bahwa orang belajar dengan cara-cara yang berbeda.

\section{METODE}

Penelitian ini merupakan jenis penelitian eksperimen semu (quasi-experimental) yang didesain dalam bentuk non-equivalent (pre-test and post-test) control-group design [14]. Penelitian ini dilaksanakan pada siswa kelas VII SMP Negeri 1 Soe, Kabupaten Timor Tengah Selatan yang terdiri dari 11 rombongan belajar dengan jumlah populasi 339 orang. Pengambilan sampel dalam penelitian ini menggunakan teknik Intact Group Random Sampling, yaitu teknik pengambilan sampel yang dirandom adalah kelas sebagai kelompok utuh (Intact Group). Sampel dari peneitian ini adalah kelas VII.11, VII.7 dan VII.5 ketiga kelas yang telah terpilih selajutnya dipilih lagi secara acak untuk menentukan kelas eksperimen 1, kelas eksperimen 2 dan kelas kontrol. Berdasarkan uji kemampuan yang diberikan menunjukan bahwa kemampuan akademik pada ketiga kelas sampel sama. Ketiga kelas sampel sebelum diberikan perlakuan diberikan tes kemampuan pemecahan masalah. Kelas eksperimen 1 akan diberikan perlakuan dengan pembelajaran model SAVI berpendekatan kontekstual kelas eksperimen 2 diberikan perlakuan pembelajaran model SAVI sedangkan 


\section{- - - Jurnal Pendidikan Matematika Indonesia \\ Volum 1 Nomor 1 bulan Maret 2016. Halaman 14-19 \\ p-ISSN: 2477-5967 e-ISSN: 2477-8443}

kelas kontrol menggunakan pembelajaran konvensional

Pengumpulan data pada penelitian ini menggunakan instrumen tes kemampuan pemecahan masalah matematika dengan bentuk tes esai atau uraian. Uji coba instrumen yang dilakukan pada tes kemampuan pemecahan masalah matematikal. Teknik pengumpulan data pada penelitian ini menggunakan tes, kuesioner/angket dan observasi. Analisis data kuantitatif menggunakan uji $\mathrm{t}$ satu sampel, uji anova.

\section{HASIL DAN PEMBAHASAN}

Hasil penelitian menunjukkan kemampuan pemecahan masalah siswa mencapai ketuntasan baik secara individual maupun klasikal. Berdasarkan hasil perhitungan diperoleh nilai thitung $=8,012$; taraf signifikan 5\% dan $\mathrm{dk}=(\mathrm{n}-1)$ $=(31-1)=30$ sehingga nilai tTabel $=2,042$ maka thitung > tTabel yang berarti H0 ditolak dan menerima $\mathrm{H} 1$. Hal ini menunjukan bahwa ratarata kemampuan pemecahan masalah siswa melampaui rata-rata asumsi populasi yakni 70 dan tuntas secara individual. Selanjutnya untuk ketuntasan klasikal dari perhitungan diperoleh nilai siswa yang mendapat nilai tes kemampuan pemecahan masalah siswa dengan KKM 70 adalah $75 \%$, dengan diperoleh nilai zhitung $=2,443$ dan $\mathrm{z}$ Tabel $=1,64$ sehingga $\mathrm{z}$ hitung $>\mathrm{z}$ Tabel maka dapat dikatakan bahwa siswa yang diajarkan dengan model SAVI berpendekatan kontekstual tuntas secara klasikal. Dengan demikian, dapat disimpulkan bahwa kemampuan pemecahan masalah siswa pada kelas yang mendapat pembelajaran model SAVI berpendekatan kontekstual mencapai ketuntasan minimal. Hal ini berarti bahwa implementasi model tersebut dalam pembelajaran mempunyai pengaruh positif terhadap kemampuan pemecahan masalah siswa. Sebagaimana penelitiannya [15] menyatakan bahwa kemampuan pemecahan masalah siswa setelah diterapkan dengan model pembelajaran SAVI mengalami peningkatan dari hasil yang diperoleh melalui suatu proses belajar mengajar sebelumnya.

Kegiatan pembelajaran yang berlangsung merupakan proses untuk meningkatkan kemampuan pemecahan masalah siswa melalui pembelajaran model SAVI berpendekatan kontekstual. Kegiatan belajar yang dilangsungkan membentuk siswa lebih aktif dalam pembelajaran karena siswa memanfaatkan semua panca indra dalam berproses. Siswa diberi kesempatan untuk menggerakkan tubuh dengan berbagai kegiatan yang dirancang dalam pembelajaran sehingga tidak membuat siswa duduk diam di depan penceramah dan mendengar saja tetapi siswa mencari informasi sendiri, berdiskusi serta mempresentasikan akan hasil diskusi mereka. Sebagaimana [15] dalam penelitiannya bahwa Siswa menjadi lebih aktif serta berani dalam mengungkapkan pendapatnya, siswa mulai dapat bekerjasama dalam kelompok yang heterogen, siswa juga mulai mahir dalam menyelesaikan soal tes keterampilan pemecahan masalah secara mandiri setelah diajarkan dengan model pembelajaran SAVI.

Melalui Pembelajaran model SAVI berpendekatan kontekstual setiap siswa dituntuk untuk menggerakan fisik yang banyak sehingga dapat meningkatkan proses mentalnya dan mengakibatkan belajar cenderung membangkitkan kecerdasan terpadu pada diri siswa. Seperti yang dikatakan oleh [7], bahwa dengan gerakan fisik meningkatkan proses mental oleh karena itu melibatkan gerakan tubuh dalam belajar cenderung membangkitkan kecerdasan terpadu manusia sepenuhnya. Pembelajaran dengan model SAVI juga membuat siswa dimampukan dapat menyelesaikan setiap permasalahan yang dihadapinya dengan baik dan hasil belajar yang didapat juga sangat baik. Hal ini sesuai dengan hasil temuan [16] yang menyatakan bahwa model pembelajaran SAVI berbasis Open Ended berpengaruh terhadap hasil belajar matematika.

Hasil penelitian menunjukkan bahwa kemampuan pemecahan masalah siswa pada kelas yang diajarkan dengan model SAVI berpendekatan kontekstual, kelas dengan pembelajaran model SAVI dan kelas dengan pembelajaran konvensional semuanya berbeda. Perbedaan yang ada pada ketiga kelas tersebut selanjutnya dilakukan uji lanjut untuk mengetahui perbedaan yang terjadi, sehingga diperoleh hasil bahwa kemampuan pemecahan masalah siswa pada kelas dengan pembelajaran model SAVI 
berpendekatan kntekstual lebih baik dari kelas dengan pembelajaran model SAVI dan kelas dengan pembelajaran konvensional, serta kelas dengan pembelajaran model SAVI lebih baik dari kelas dengan pembelajaran konvensional. [17] juga mengatakan hal yang sama yakni pembelajaran dengan model SAVI berbantuan alat peraga rata-rata hasil belajar pada kemampuan pemecahan masalah lebih baik dari siswa yang diajarkan dengan ekspositori.

\section{KESIMPULAN DAN SARAN}

\section{KESIMPULAN}

Berdasarkan hasil dan pembahasan melalui serangkaian pengolahan dan analisa data, dapat disimpulkan bahwa kemampuan pemecahan masalah siswa mencapai ketuntasan baik secara individual maupun klasikal. Rata-rata kemampuan pemecahan masalah siswa melampaui rata-rata asumsi populasi dan tuntas secara individual. Selanjutnya untuk ketuntasan klasikal siswa yang mendapat nilai tes kemampuan pemecahan masalah dengan KKM 70 adalah $75 \%$. Dengan demikian kemampuan pemecahan masalah siswa pada kelas yang mendapatkan model pembelajaran model SAVI berpendekatan kontekstual mencapai ketuntasan minimal.

Kemampuan pemecahan masalah siswa pada kelas dengan pembelajaran model SAVI berpendekatan kontekstual; lebih baik dari kelas dengan pembelajaran model SAVI dan lebih baik dari kelas dengan pembelajaran konvensional berbeda untuk setiap kelasnya. Kemampuan pemecahan masalah siswa pada kelas dengan pembelajaran model SAVI berpendekatan kontekstual lebih baik dari kelas dengan pembelajaran model SAVI dan juga lebih baik dari kelas dengan pembelajaran konvensional.

SARAN

Pembelajaran model SAVI berpendekatan kontekstual dapat digunakan pada topik pembelajaran yang lain dalam pembentukan kemampuan pemecahan masalah siswa. Kreatifitas guru merancang pembelajaran yang dapat membangkitkan karakter kerja keras siswa akan mendukung pencapaian tujuan dan target yang diinginkan. Kemampuan pemecahan masalah yang diukur pada penelitian ini dilihat secara klasikal, oleh karena itu disarankan kepada penelitian selanjutan yang hendak melakukan penelitian dengan model dan pendekatan yang sama bisa dilihat dari pengkategorian berdasarkan tingkat kemampuan siswa.

\section{DAFTAR PUSTAKA}

[1] Hendriana, H., \& Soemarmo, U. 2014. Penilaian Pembelajaran Matematka. Bandung: Refika Aditama.

[2] NCTM. 2000. Principles and Standards for School Mathematics. Reston: National Council of Teachers of Mathematics, Inc.

[3] Suherman, Erman H. dkk. 2003. Strategi Pembelajaran Matematika Kontemporer. Bandung: UPI.

[4] Schoenfeld, A. H. 2013. "Reflections on Problem Solving Theory and Practice" TME, 10(1\&2): 9-34.

[5] Gomez-Chacon I. M. 2013. "Prospective Teachers' Interactive Visualization and Affect in Mathematical Problem-Solving". TME, 10(1\&2): 61-68.

[6] Trianto. 2008. Mendesain Pembelajaran kontekstual. Jakarta: Cerdas Pustaka Publisher.

[7] Meier, D. 2003. Panduan Kreatif Dan efektif Merancang Program Pendidikan Dan Pelatihan Terjemahan Astuti Rahmani. Bandung: Kaifa.

[8] Rusman. 2009. Model-Model Pembelajaran (Mengembangkan Profesionalisme Guru). Jakarta: Rajawali Pers.

[9] Supinah dkk. 2008. Pembelajaran Matematika SD dengan Pendekatan Kontekstual dalam Melaksanakan KTSP. Yogyakarta: PPPPTK Matematika.

[10] Fathurrohman, P., Suryana, A. A., \& Fatriany, F. 2013. Pengembangan Pendididkan Karakter. Bandung: Refika Aditama.

[11] Budi, S. W. 2004. Langkah awal menuju olimpiade matematika. Jakarta: Ricardo

[12] Suprijono, A. 2009. Cooperative LearningTeori dan Aplikasi PAIKEM. Yokyakarta: Pustaka Pelajar.

[13] Huda, M. 2013. Model-model Pengajaran dan Pembelajaran. Malang: Pustaka Pelajar.

[14] Creswell, J. W. 2014. Research Design Pendekatan Kualitatf, Kuantitatif dan Mixed. Terjemahan Achmad Fawaid. Yogyakarta: Pustaka Pelajar.

[15] Kusumawati, S. W. \& Gunansyah, G. 2013. "Penerapan model Pembelajaran SAVI untuk Meningkatkan Ketrampilan Pemecahan Masalah di Sekolah Dasar". JPGSD, 1(2): 1-10.

[16] Utama, W. A., Suniasih, N. W. \& Putra, D. K. N. S. 2014. "Pengaruh Model Pembelajaran SAVI Berbasis Open-Endid Terhadap Hasi Belajar Matematika pada Siswa Kelas V SD Gugus III Sukawati”. Jurnal Mimbar PGSD Universitas Pendidikan Ganesha, 2(1): http://ejournal.undiksha.ac.id/index.php/JJPGSD/article/viewFile/319 0/2652. (diunduh 6 Januari 2015).

[17] Mariya, D., Mastur, Z., \& Pujiastuti, E. 2013. "Keefektifan Pembelajaran SAVI Berbantuan Alat Peraga Terhadap Kemampuan Pemecahan Masalah". UJMME, 2(2) http://journal.unnes.ac.id/sju/index.php/ujme (diunduh 11 Desember 2014). 